We all choose, or are driven, to be excited not by all of science itself, but by some more limited domain; Leroi is driven by a fascination with the morphology of race and, more personally still, by the biology of beauty. I too know the effect of a mutation in the MC1R gene, which is responsible for redheads, and I know that it is beautiful. Leroi draws tight his net of wonderful human diversity and gracefully displays its contents, and I am full of admiration for his willingness to build on his declared prejudice.

Despite its subject matter, Mutants is an exquisitely life-enhancing book. It captures what we know of the development of what makes us human, and it recognizes the random tragedy inflicted by nature and nurture. Read the book and you will be exposed to both a scientific world that no longer exists and to that of the twenty-first century. Read it and you will know a tiny part of what it is that has made you the person you are. Read it and enjoy words written carefully, elegantly and with sensibility. Read it and marvel.

Peter Little is at the School of Biotechnology and Biomolecular Science, University of New South Wales, Sydney, New South Wales 2052, Australia.

\section{Watching the Earth move}

\section{Pendulum: Léon Foucault and the Triumph of Science \\ by Amir D. Aczel \\ Atria: 2003. 288 pp. $\$ 25$}

\section{Michael Matthews}

Léon Foucault (1819-1868) is known to millions by virtue of science museums around the world displaying his pendulum. Foucault's pendulum gained even wider recognition as the title of a best-selling novel by Umberto Eco. But although Foucault's name is widely recognized, knowledge about him, even among scientists and historians of science, is thin. This scientific and social biography by Amir Aczel, who has written several popular-science books including Fermat's Last Theorem (Four Walls Eight Windows, 1996), should rectify this problem.

Foucault experienced similar travails to those endured by John Harrison, another pendulum enthusiast and the protagonist of Dava Sobel's best seller Longitude (Walker, 1995). Both men came from outside their country's scientific establishment, both were long rejected by the establishment, both were given recognition by 'royal' decree, and both enjoyed their rightful fame only at the end of their lives. But whereas Harrison was predominantly a technician who worked for 17 years on the construction of a single pendulum clock, Foucault had

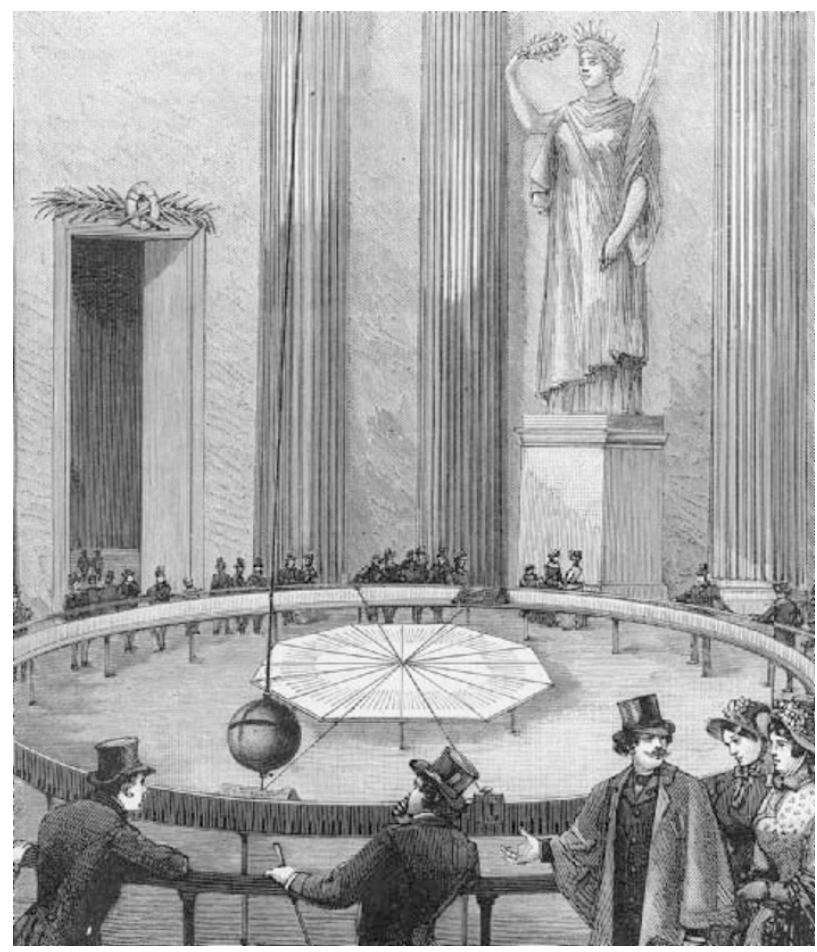

In full swing: Léon Foucault's pendulum revealed the Earth's rotation.

scores of scientists, mathematicians and savants duly gathered behind a wooden balustrade that marked off the oscillation space of an 11-metre heavy pendulum that swung along the markedout Paris meridian. Once the pendulum was set swinging, the Earth moved before the eyes of the audience. The plane of oscillation of the pendulum slowly but perceptibly altered. Foucault's clever handiwork had ensured that there was no torque force on the pendulum, so the only conclusion to be drawn was that the Earth had moved.

This was the first dynamical proof of Earth's rotation - something that had eluded natural philosophers and scientists since Pythagorus and

much wider technical and scientific interests.

As a small boy, Foucault suffered numerous illnesses. One of his eyes was myopic and the other was far-sighted. A friend wrote of him that "the feebleness of his constitution and the slowness that characterized his work made it impossible for him to frequent a college". He could therefore pursue his studies only with help from a devoted tutor, "under the watchful eyes of his mother". But he did have a gift for working with his hands.

The combination of dogged and skilled handiwork with scientific interest and competence were the foundations of his scientific successes. For example, he improved the daguerreotype method to obtain the first ever 'photograph' of the Sun showing its sunspots. He also constructed a massive (190-centimetre) but finely accurate reflecting telescope that was engine-driven to compensate for Earth's rotation; this instrument contributed significantly to Urbain-JeanJoseph Le Verrier's astronomical triumphs. In 1850 Foucault determined the speed of light to be 298,000 kilometres per second, which is within $0.6 \%$ of the current accepted value. And in 1851 he made the world's first gyroscope that could be pointed towards true north, thereafter holding its position and thus being a non-magnetic and superbly accurate compass.

But Foucault's fame rests on his pendulum demonstration, which rightly takes centre stage in Aczel's book. On 2 February 1851, Foucault sent to all known scientists in Paris a simple invitation that read: "You are invited to come to see the Earth turn, tomorrow, from three to five, at the Meridan Hall of the Paris Observatory." The following day,
Aristarchus in the ancient world proposed that it was Earth that rotated, rather than the heavens that rotated around a stationary Earth. Copernicus had resurrected the heliocentric, rotating-Earth theory in 1543; Galileo defended the view in the early seventeenth century; Newton and other leading astronomers and scientists also adopted the position. But with enough determination and conviction, all of their astronomical evidence could be reconciled with the stationary-Earth theory. Tycho Brahe took this option, and so did the Catholic Church, which kept all 'rotating Earth' publications on the Index of Forbidden Books until as late as 1835.

Aczel's book benefits from his study of original sources, including those in the French Academy of Sciences, the French National Library and the Paris Observatory. The book nicely connects Foucault to his political, social and scientific times. It details the generous support that Foucault received from Louis-Napoléon Bonaparte after the scientific establishment had all but ignored him. Aczel rightly highlights the question of why it was that so simple a demonstration of the moving Earth had eluded the roll-call of geniuses who had sought it. And he also asks why the French Academy of Sciences resolutely refused membership to Foucault not only before his demonstration, but for 15 years afterwards.

Michael Matthews is at the School of Education, University of New South Wales, Sydney, Australia. He is the author of Time for Science Education: How Teaching the History and Philosophy of Pendulum Motion Can Contribute to Science Literacy (Kluwer, 2000). 